\title{
DEPOSITIONAL ENVIRONMENTS OF TERTIARY TURBIDITIC SEDIMENTS IN METSOVO BASIN, NW GREECE
}

\author{
G. ANANIADIS ${ }^{1}$ \& A. ZELILIDIS ${ }^{1}$
}

\begin{abstract}
Tertiary sediments in Metsovo area consist of submarine fan turbidite deposits accumulated in the proximal part of the basin and represent mostly inner fan. The most proximal part of the inner fan could be related to a shelf environment. Palaeocurrent data indicate mainly two directions. The main direction is SW and results mainly from groove marks. The second direction represents an WNW trend which results mainly from flute marks. The Metsovo area seems to have multiple feeders from North and East. The total thickness of the turbiditic deposits in Metsovo area is approximately $6800 \mathrm{~m}$ due to tectonic stacking and folding.
\end{abstract}

KEY WORDS: Metsovo basin; submarine fan; turbidites; sole marks.

\section{INTRODUCTION AND GEOLOGICAL SETTING}

Submarine fans are constructional features on the see floor that develop seaward of a major sediment point source (Stow et al. 1996). According to Ricci Lucchi (1975) the development of a submarine fan is characterized by four major elements:(a)inner fan, (b) middle fan, (c)outer fan and (d)basin plain. The inner fan represents the proximal part of the submarine fan and consists of channel-fill, interchannel, levee and mouth bar deposits. The middle fan is characterized by both inner and outer fan features. The outer fan consists of lobes and lobefridge deposits. The basin plain represents the most distal parts of the fan and consists of mudstone and siltstone sediments. The transport of the sediment is made by turbidity currents. The sediment is sustained by fluid turbulence and deposited when velocity and gradient are reduced.

The sequence of sedimentary structure in turbidity beds are known as the Bouma sequence (Bouma, 1962). The ideal deposits of a turbidity current contains the complete $\left(\mathrm{T}_{\mathrm{ae}}\right)$ Bouma sequence which it consists from base to top of massive sand $\left(\mathrm{T}_{\mathrm{a}}\right)$, laminated sand $\left(\mathrm{T}_{\mathrm{b}}\right)$, rippled or convoluted sand $\left(\mathrm{T}_{\mathrm{c}}\right)$, laminated silt-sand $\left(\mathrm{T}_{\mathrm{d}}\right)$ and laminated mud $\left(\mathrm{T}_{\mathrm{e}}\right)$.

The hydraulic conditions during the development of the turbidity currents are estimated from the grain size, structures and direction of flow. The palaeocurrent direction in a ancient submarine fan can be derived from erosional structures such as sole marks, ripple lamination and channels.

The Metsovo area is located in Northwestern Greece and belongs to the Pindos zone (Fig. 1). The area aligns parallel to the external Hellenides, that consist, from east to west, of the Pindos, Gavrovo, Ionian and the Pre-Apulian geotectonic zones (Aubouin, 1965). The external Hellinides represent parts of the Apulian plate which were separated from the Pelagonian microplate by the Pindos ocean (Robertson et al. 1991; Jones et al., 1992). The Pindos zone corresponds to the western marginal domain of the Pindos ocean. The terminal flysch deposition commenced in the Palaeocene and lasted until Oligocene times (Koch and Nicolaus, 1969; Fleury, 1980; Richter, 1993; Richter et al., 1993).

The Metsovo area is bounded from the Pindos Thust to the west and from the Pindos ophiolite to the east (Fig. 1). The Pindos flysch in Metsovo area according to Aubouin $(1959,1964)$ was deposited between Maestrichtian - Priabonian time. Lorsong (1977) referred to the area as Politses formation dividing the Pindos flysch (Metsovo area in this work) into members, based on outcrops in different places and not in detailed mapping. The four members from base to top are: the Chrisovitsa Member (red shales and limestones), the Ilias Member (turbidite conglomerates and sandstones), the Karakoli Member (thin bedded turbidites) and the Keramari Member (thick bedded turbidites). The succesion of sediments exist in at least 18 tectonic units bounded by high-angle thrust surfaces (Lorsong, 1977). Moreover Lorsong (1977), believes that the stratified part of the Pindos flysch in Metsovo is approximately $530 \mathrm{~m}$, although Aubouin (1959) suggested thickness between $1000 \mathrm{~m}$ and $2000 \mathrm{~m}$ or more. According to Katsiavrias (1983), the base of the formation is not the red shales of Chrisovitsa Member but gray bluish massive non-bedded marls.

1. Department of Geology, University of Patras, 26500 Patras 


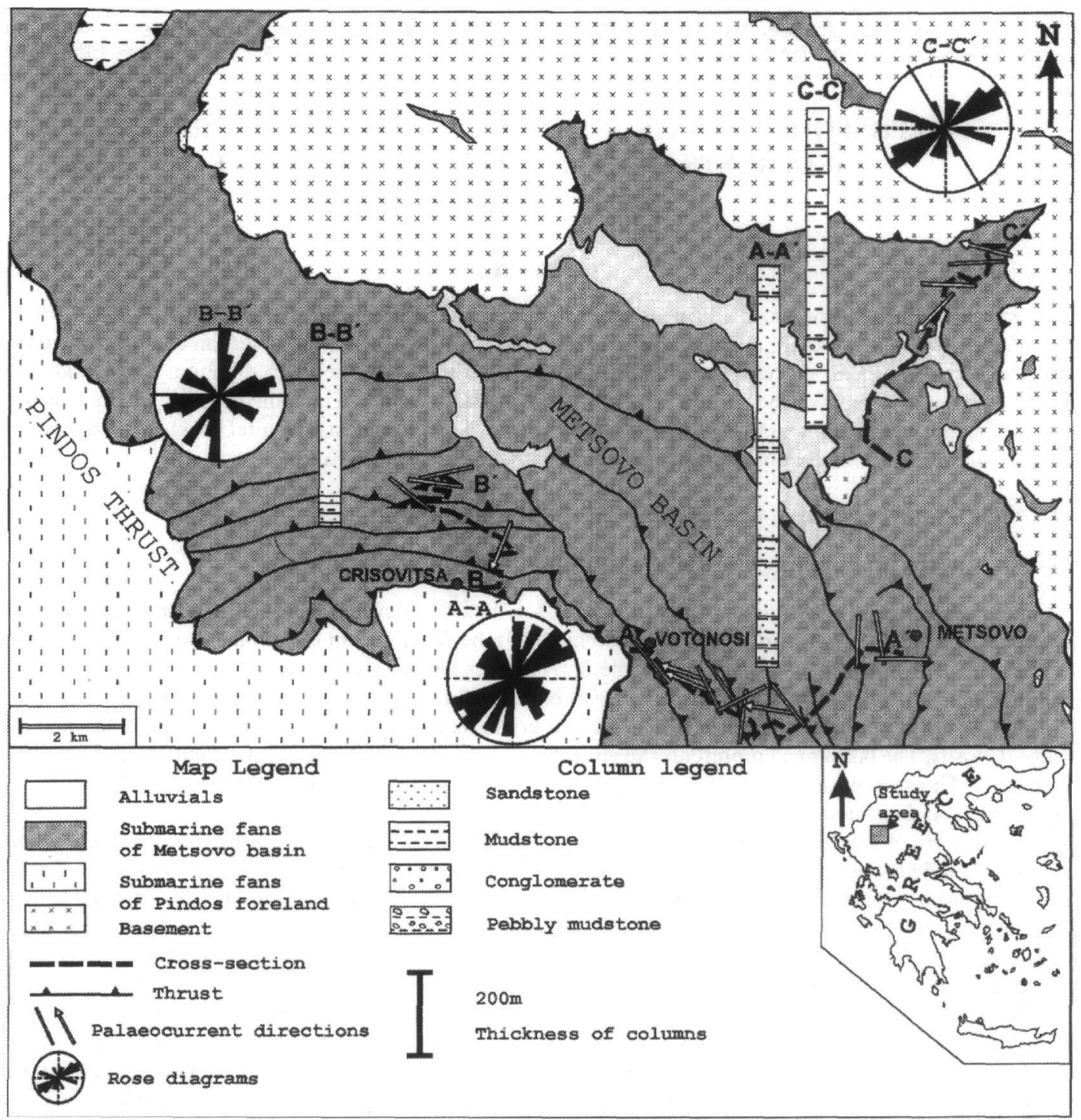

Fig.1 Geological map of the study area. Includes roses, palaeoflow trends and columns for each cross-section.

The aim of this paper is to study the sedimentary successions of the Tertiary turbiditic deposits in the Metsovo basin in order to understand and recognize the depositional conditions and depositional environments that formed in the Metsovo basin which is part of the Pindos zone. Moreover, palaeocurrent analysis will give informations about the feeding sources of the sediments.

\section{DEPOSITIONAL ENVIRONMENTS}

In order to better understand the depositional setting and stratigraphic architecture, the sediments in Metsovo area have been studied in three main cross-sections (fig.1). The first cross-section (A-A') is situated in the central part of the area along the main road Votonosi-Metsovo (Fig. 2). The second cross- section (B-B') is situated in the western part of the area (Fig. 3) and the third cross-section (C-C') in the eastern part of the area (Fig.4). 


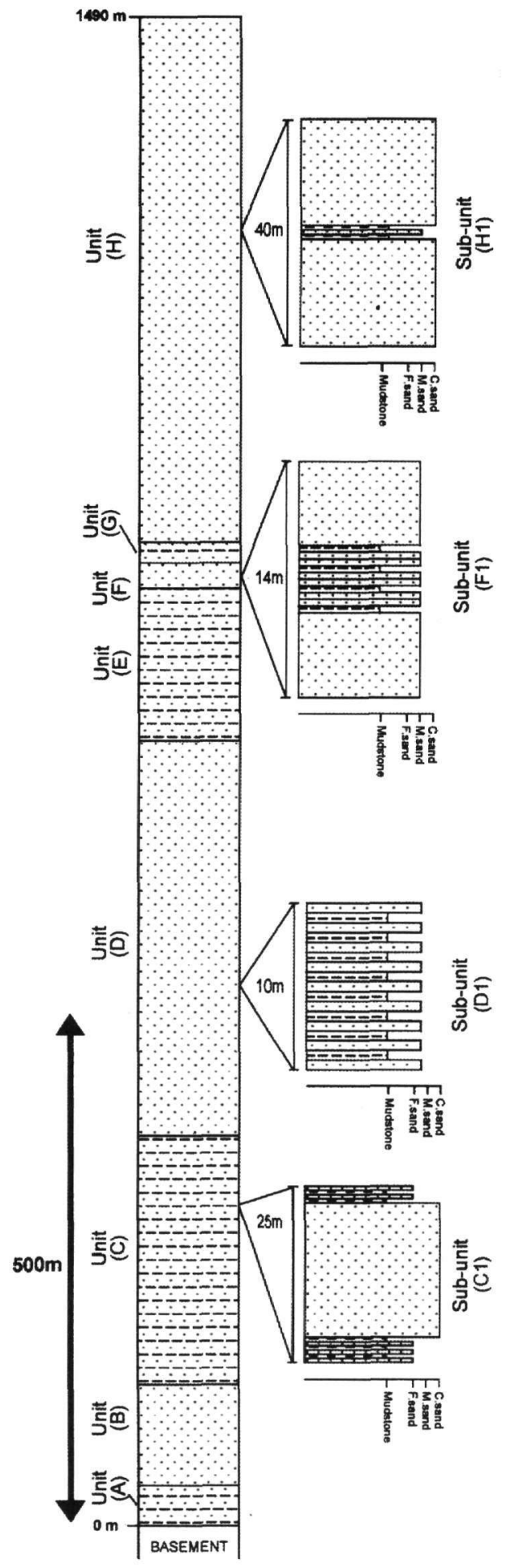

\section{Cross-section A-A'(Votonosi-Metsovo)}

H) Coarse brown sandstones with total thickness of $520 \mathrm{~m}$ and maximum bed thickness $5 \mathrm{~m}$. The sandstones are characterized mostly by $\mathrm{T}_{\mathrm{a}}$ intervals. A sub-unit of cyclic alternations up to $2 \mathrm{~m}$ thick consists of medium brown sandstone and greyish mudstone with s:m ratio 1:1 (H1).

G) Cyclic alternations with total thickness up to $20 \mathrm{~m}$ of brown greenish sandstones and grayish mudstones with $\mathrm{s}: \mathrm{m}$ ratio $1: 1$. The maximum thickness of the sandstone bed is $20 \mathrm{~cm}$. The sandstone is characterized mostly by Tc Bouma ripple lamination.

F) Medium brown sandstones with total thickness of $25 \mathrm{~m}$ and maximum bed thickness 2,5 m. Bouma interval $\mathrm{T}_{\mathrm{a}}$ is mostly present. A sub-unit of cyclic alternations up to 5 $\mathrm{m}$ thick consist of medium brown sandstones and greyish mudstone with s:m ratio 2:1 (F1).

E) Cyclic alternations up to $150 \mathrm{~m}$, of medium to fine brown greenish sandstones and grayish mudstones with s:m ratio 1:1. The maximum thickness of the sandstone bed is $20 \mathrm{~cm}$. The sandstone is characterized mostly by $T_{c}$ Bouma interval which represent ripple lamination.

D) Coarse to medium grey sandstone with total thickness of $390 \mathrm{~m}$ and maximum bed thickness $1 \mathrm{~m}$. Little black rounded clasts exist in the lower part of the sandstone beds. Bouma interval $\mathrm{T}_{\mathrm{a}}$ is present. A sub-unit of cyclic alternations up to $10 \mathrm{~m}$ thick consists of medium to fine brown sandstones and mudstones with s:m ratio 1:1(D1).

C) Cyclic alternations with total thickness up to $245 \mathrm{~m}$ of fine brown greenish sandstones and grayish mudstones with s:m ratio 1:1. The maximum thickness of the sandstone bed is $60 \mathrm{~cm}$. The sandstone is characterized by $\mathrm{T}_{\mathrm{bc}}$ Bouma intervals. Tc represents ripple lamination. Two sub-units consist of coarse gray sandstones with maximum bed thickness $3 \mathrm{~m}$ and total thickness $20 \mathrm{~m}$ (C1) and $35 \mathrm{~m}$ each. They are characterized mostly by $\mathrm{T}_{\mathrm{a}}$ Bouma interval.

B) Coarse to medium brown sandstones with total thickness $100 \mathrm{~m}$ and maximum bed thickness up to $5 \mathrm{~m}$. $\mathrm{T}_{\mathrm{a}}$ Bouma interval is present.

A) Cyclic alternations, of thin-bedded fine gray sandstones and greyish mudstones with s:m ratio 1:1. Total thickness up to $40 \mathrm{~m}$. The sandstones are characterized by $\mathrm{T}_{\mathrm{bc}}$ Bouma intervals. Tc represents ripple lamination. Continue.. 


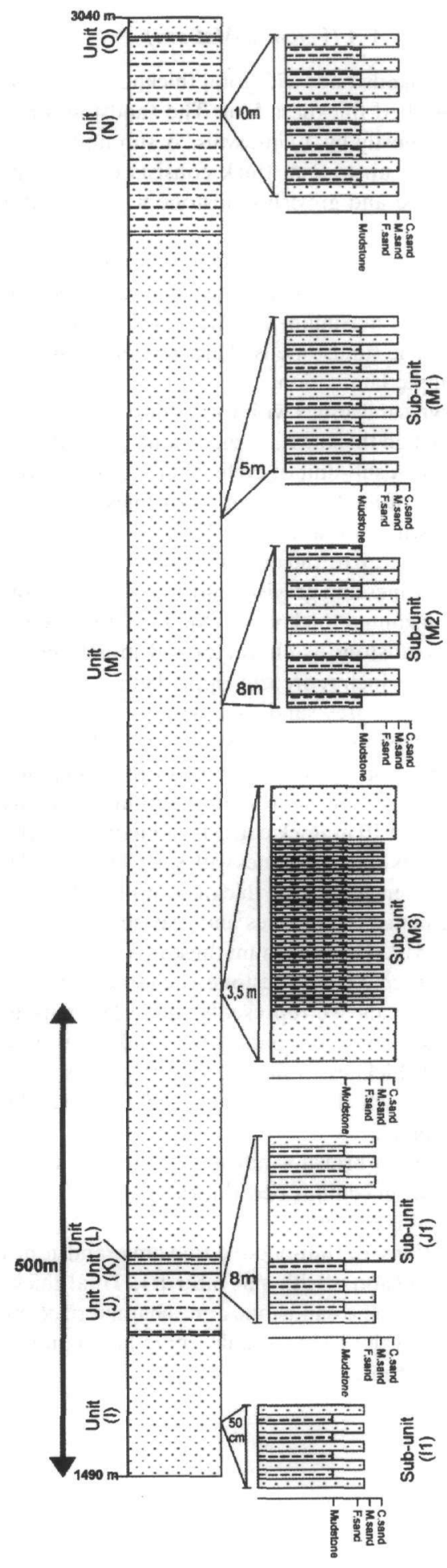

O) Medium gray sandstones with thickness of $20 \mathrm{~m}$ and maximum bed thickness $1,5 \mathrm{~m}$. They are characterized mostly $\mathrm{T}_{\mathrm{a-c}}$ by Bouma intervals, groove casts and rills. The Tc Bouma interval represents ripple and convolute lamination.

N) Cyclic alternations with total thickness up to $210 \mathrm{~m}$ of medium greenish gray sandstones and grayish mudstones with s:m ratio $1: 1$. The sandstones are characterized by $T_{b c}$ Bouma intervals. Tc Bouma interval is represented by ripple and convolute lamination.

M) Coarse gray mica sandstone beds with total thickness of $1085 \mathrm{~m}$ and maximum bed thickness $2,5 \mathrm{~m}$. The sandstones are characterized by normal grading and mostly $\mathrm{T}_{\mathrm{a}}$ Bouma interval. Small reddish rounded clasts are present in the lower part of the sandstone beds. In the upper part a sub-unit is intercalated up to $10 \mathrm{~m}$ thick, consisting of alternated medium gray sandstones and grayish mudstones with s:m ratio 1:1 with thickness of $10 \mathrm{~m}$ (M1). Bouma intervals $\mathrm{T}_{b c}$ are present. Ripple and convolute lamination represent the $\mathrm{T}_{c}$ Bouma interval. In the middle part a sub-unit is formed of cyclic alternated medium gray sandstones and grayish mudstones with s:m ratio 2:1 (M2) and thickness up to $10 \mathrm{~m}$. The sandstones are characterized by $\mathrm{T}_{\mathrm{a}-\mathrm{c}}$ Bouma intervals with Tc to represent ripple and convolute lamination. Carbonate clasts within the laminated sandstone beds are present. In the lower part a sub-unit of cyclic alternations up to 2,5 m consists of medium gray sandstones and grayish mudstones with s:m ratio 1:1 and maximum bed thickness $5 \mathrm{~cm}$ (M3) are.

L) Grayish mudstone with total thickness of $10 \mathrm{~m}$.

K) Medium gray sandstones, with total thickness of $10 \mathrm{~m}$, are characterized by $\mathrm{T}_{\mathrm{bc}}$ Bouma intervals. $\mathrm{T}_{\mathrm{c}}$ corresponds to ripple lamination.

J) Cyclic alternations up to $65 \mathrm{~m}$ of medium to fine brown sandstones and grayish mudstones with $\mathrm{s}: \mathrm{m}$ ratio $1: 1$. The maximum thickness of the sandstone bed is $40 \mathrm{~cm}$. The sandstone is characterized by $\mathrm{T}_{\mathrm{bc}}$ Bouma intervals. Carbonate clasts are aligned to the lamination. The Tc interval is represented by ripple lamination. A sub-unit consists of coarse grey sandstones with total thickness of $20 \mathrm{~m}$ (J1) and maximum bed thickness of $2,5 \mathrm{~m}$.

I) Coarse gray sandstones with total thickness of $150 \mathrm{~m}$ and maximum bed thickness $2,5 \mathrm{~m}$. Bouma intervals $\mathrm{T}_{\mathrm{a}-\mathrm{c}}$ are present.Tc refered to ripple and convolute lamination. A sub-unit of cyclic alternations up to $20 \mathrm{~m}$ which consists of thin-bedded fine to medium gray sandstones and grayish mudstone with s:m ratio 1:1 (I1) is also present.

Figure 2. Geological cross-section A-A', with a total stratigraphic thickness up to $3040 \mathrm{~m}$, exposed in the central part of the area. This section could be divided in 15 units. For location and explanation of symbols see figure 1. 


\section{Cross-section B-B}

I) Medium gray sandstone with maximum bed thickness 40 $\mathrm{cm}$ and total thickness $65 \mathrm{~m}$. The sandstone is highly deformed and characterized by $\mathrm{T}_{\mathrm{a}}$ Bouma interval.

$\mathrm{H})$ Medium to fine brown grayish sandstones with total thickness of $370 \mathrm{~m}$ and maximum bed thickness of $75 \mathrm{~cm}$. The sandstone is characterized by $\mathrm{T}_{\mathrm{a}-\mathrm{c}}$ Bouma intervals, water-escape structures and groove marks. $\mathrm{T}_{\mathrm{c}}$ Bouma interval represents ripple and convolute lamination. Coal horizons are abundant. Several sub-units of total thickness up to $150 \mathrm{~m}$ consist of cyclic alternations of fine brown grayish sandstones and mudstones with s:m ratio 1:1 (H1). The maximum thickness of the sandstone bed is $10 \mathrm{~cm}$. The sandstone is characterized by $\mathrm{T}_{\mathrm{acc}}$ Bouma intervals, slump horizons and groove marks. $\mathrm{T}_{\mathrm{c}}$ Bouma interval represent ripple lamination.

G) Red and green mudstone with thickness of $60 \mathrm{~m}$. In places a sub-unit with thin-bedded fine brown sandstones is present.

F) Coarse gray sandstones with total thickness up to $620 \mathrm{~m}$ and maximum bed thickness of $2 \mathrm{~m}$. Bouma intervals $T_{a}$ $c$ are present. $T_{c}$ represents ripple lamination. In some places the sandstone is deformed. In the upper part a subunit of red and green mudstone with thickness of $190 \mathrm{~m}$ (F1) is present. In the lower part another sub-unit of highly tectonized bluish gray mudstone with thickness of approximately $80 \mathrm{~m}(\mathrm{~F} 2)$ is present.

E) Cyclic alternations with total thickness $50 \mathrm{~m}$ of highly deformed medium brown sandstones and brown mudstones with s:m ratio 1:1. The maximum thickness of the sandstone bed is $30 \mathrm{~cm}$. The sandstone is characterized by $\mathrm{T}_{\text {ac }}$ Bouma intervals. $T_{c}$ represents convolute lamination.

D) Cyclic alternations up to $60 \mathrm{~m}$ of medium to fine brown sandstones and greyish mudstones with s:m ratio 1:9. The sandstone bed maximum thickness is up to $90 \mathrm{~cm}$. Bouma intervals $T_{a-c}$ and flute casts are present in the sandstone beds. $T_{c}$ Bouma interval represent ripple lamination. In the upper part a sub-unit which consists of gray mudstone with thickness of $5 \mathrm{~m}$ (D1) is present.

C) Brown greenish mudstone with thickness of approximately $20 \mathrm{~m}$.

B) Cyclic alternations up to $70 \mathrm{~m}$ of medium brown sandstones and grayish mudstones with s:m ratio 9:1. The maximum thickness of the sandstone bed is $1 \mathrm{~m}$. The sandstone is characterized by $\mathrm{T}_{\mathrm{acc}}$ Bouma intervals. Ripple and convolute lamination characterize $T_{\text {c }}$.

A) Cyclic alternations with total thickness up to $30 \mathrm{~m}$ of medium brown sandstones and brown mudstones with s:m ratio $1: 1$. The maximum thickness of the sandstone bed is $30 \mathrm{~cm}$. The sandstone is characterized by $\mathrm{T}_{a c}$ Bouma intervals. $T_{c}$ represents convolute lamination. 


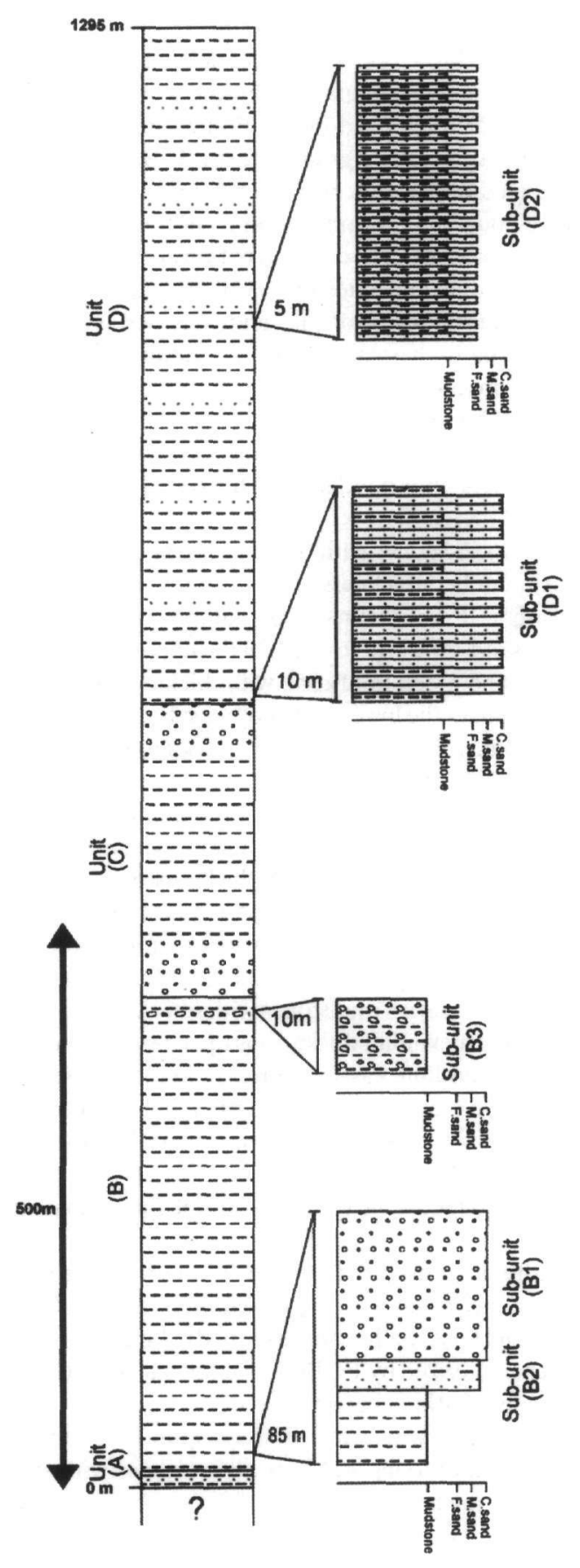

\section{Cross-section C-C}

D) Alternated up to $600 \mathrm{~m}$ thick fine gray sandstones and bluish mudstones with s:m ratio between 1:9 and 1:1. The sandstone is characterized by many coal clasts. In the upper part of the unit a sub-unit up to $155 \mathrm{~m}$ thick with alternated coarse brown sandstones and mudstones with s:m ratio 2:1 (D1) was formed. The maximum thickness of the sandstone bed is $40 \mathrm{~cm}$. The sandstone is deformed and characterized by $\mathrm{T}_{\mathrm{a}}$ Bouma interval and abundant coal clasts. Small rounded clasts appear in the lower part of the sandstone bed. In the middle part of the unit a sub-unit consisting of alternated fine gray sandstones and grayish mudstones with s:m ratio 1:1 (D2) up to $20 \mathrm{~m}$ thick is present. The maximum thickness of the sandstone bed is $20 \mathrm{~cm}$. The sandstone beds are characterized by many coal clasts, sole marks and Tbc Bouma intervals. The $\mathrm{T}_{\mathrm{c}}$ Bouma interval is represented by ripple lamination.

C) Bluish mudstone with thickness of $260 \mathrm{~m}$. In the upper and lower part of the unit intercalates a sub-unit which consists of conglomerate (B1) with total thickness of 100 $\mathrm{m}$.

B) Greenish brown mudstone with total thickness of about $420 \mathrm{~m}$. In some places a sub-unit consisting of thin-bedded brown sandstone with maximum bed thickness $4 \mathrm{~cm}$ was formed. The sandstone is characterized by $\mathrm{T}_{\mathrm{a}}$ Bouma interval and coal clasts. In the top of this unit a sub-unit which consists of conglomerate with thickness of about $50 \mathrm{~m}$ (B1) is present. The conglomerate is coarsegrained, poorly sorted, clast-supported gravel lacking internal organization with sand matrix. Clasts are sandstone and limestone with $\mathrm{Lmax} 30 \mathrm{~cm}$. In some places the conglomerate alternates with coarse to medium brown sandstones and brown mudstones with s:m ratio between 9:1 and 2:1 with total thickness up to $10 \mathrm{~m}$ (B2). The maximum thickness of the sandstone bed is $80 \mathrm{~cm}$. In the bottom of the unit intercalates a sub-unit which consists of bluish pebbly mudstone with thickness of about $10 \mathrm{~m}$ (B3), is poorly sorted with no internal organization. The pebbles are sandstone with Lmax $20 \mathrm{~cm}$.

A) Alternated thin-bedded fine reddish to brown sandstones and reddish mudstones with s:m ratio between $1: 1$ and 1:9 and total thickness up to approximately $15 \mathrm{~m}$. The sandstone beds are characterized by $\mathrm{T}_{b c}$ Bouma intervals. $T_{c}$ represents ripple lamination.

Continue.. 


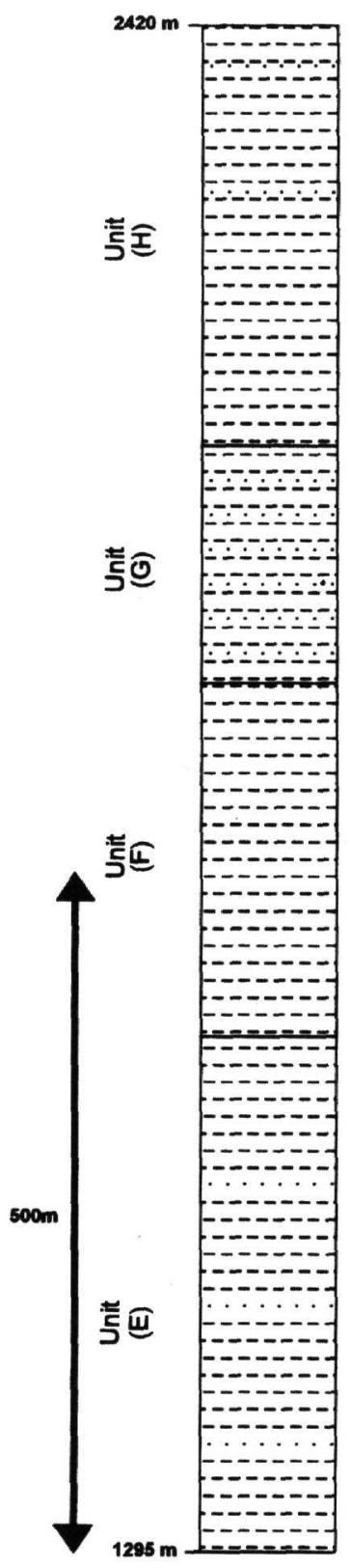

Figure 4. Geological cross-section C$C^{\prime}$, with total stratigraphic thickness up to $2420 \mathrm{~m}$ thick, exposed in the Northwest part of the area. This section could be divided in 8 units.ll For location and explanation of symbols see figure 1 .
H) Grayish mudstone with thickness of $310 \mathrm{~m}$. In some places a sub-unit which consists of thin-bedded sandstones is present.

G) Cyclic alternations up to $175 \mathrm{~m}$ of thin-bedded coarse brown sandstones and grayish mudstones with s:m ratio between 2:1 and 1:1. The sandstone is characterized by $\mathrm{T}_{\mathrm{ab}}$ Bouma intervals and groove marks. Coal horizons are abundant, aligned to the lamination of the sandstone beds.

F) Bluish mudstone, $260 \mathrm{~m}$ thick.

E) Cyclic alternations up to $380 \mathrm{~m}$ which consist of medium brown reddish sandstones and brown mudstones with s:m ratio between 1:6 and 1:9. The sandstones are characterized by $\mathrm{T}_{\mathrm{a}-\mathrm{c}}$ Bouma intervals and sole marks. The $T_{c}$ Bouma interval is represented by ripple lamination.

\section{INTERPRETATION}

Bouma sequence presence, within the studied sedimentary successions, indicates that submarine fans filled up the basin. The channelized geometry of the sandstones, the presence of conglomerates and slump horizons indicate that the whole studied deposits accumulated in the proximal part and mostly represent the inner fan sub-environment. The units of alternated thin bedded sandstones and mudstones with s:m ratio 1:1 (Figure 2, units: A, C, E, G, J, N, sub-units: D1, H1, I1, M1, M3 ; Figure 3, units: A, E, sub-units H1; Figure 4, unit: G, sub-unit: D2) are interpreted as levees and interchannel deposits. The units of mudstones (Figure 2, unit: L; Figure 3, units: C, G, sub-units: D1, F1, F2; Figure 4, unit: H), and alternated cylces with sandstones and mudstones and s:m ratio 1:9 (Figure 3, unit: D; Figure 4, unit: E) are interpreted as levee mudstones. The thick mudstone units (Figure 4, units: B, C, F) may represent shelf deposits. Medium, coarse sandstone (Figure 2, units: B, D, F, H, I, K, M, O, sub-units: C1, J1; Figure 3, units: B, F, H, I; Figure 4, sub-units: B2) and conglomerate units (Figure 4, unit C, sub-unit: B1) are interpreted as channel deposits. The pebbly mudstone horizon (figure 4, sub-unit: B3) represents sediments that deposited in the slope area and formed due to slump and slide.4.

\section{PALAEOCURRENT ANALYSIS}

The palaeoflow trends have been estimated from the sole marks at the base of the sandstone beds. For sole marks which are hosted in beds with gradient greater than $25^{\circ}$ the rose diagrams have been rotated. The projection of the mean palaeocurrent directions in the rose diagrams show two palaeoflow directions for cross- section A-A' (NE-SW and NW) and three direction for cross-sections B-B' (SWS, WNW-ESE and WSW-ENE) and C-C' (WNW, SW and E-W) (Fig. 1).

\section{DISCUSSION AND CONCLUSIONS}

The Metsovo area according to the interpretation of the three studied cross-sections indicates the proximal part of the submarine fan and represents the inner fan. The central and western parts of the Metsovo area represent the inner fan. The eastern part of the area represents the most proximal part of the inner fan and maybe a part of a shelf. The results from the palaeocurrent data indicate mainly two directions. The main direction is SW and the minor is WNW. The Metsovo basin seems to have multiple feeders from North and East, maybe the basement of Pindos. This hypothesis agrees in general with the palaeocurrent directions proposed by Richter (1993) and Bonorino (1996).

The total thickness of the flysch deposits in Metsovo area is approximately $6805 \mathrm{~m}$. This thickness represents the total exposed thickness which 
includes possible increasement of the thickness due to tectonic stacking and folding of the submarine fan deposits. Although there are not many sedimentary horizons for correlation either in the same section or between adjacent sections researchers proposed different thickness of the flysch deposits in this area. Lorsong (1977) suggest $530 \mathrm{~m}$, while Aubouin (1959) and Richter et al. (1993) proposed thickness of $1000 \mathrm{~m}$ to $2000 \mathrm{~m}$ or more. In order to estimate the exact stratigraphic thickness more detailed work is needed, dating and describing the exposed sediments. Our estimation is that the real thickness is more than $1000 \mathrm{~m}$ but less than $6805 \mathrm{~m}$.

\section{REFERENCES}

AUBOUIN, J., 1959. Contribution à l' étude géologique de la Grèce septentrionale: les confins de l'Epire et de la Thessalie: Ann. Géol. des Pays Hell., 10, 1-184.

AUBOUIN, J., 1964. Reflection sur le problème des Flyschs et des Molasses: son aspect das les Hellènides (Grèce):Eclogae Geolologicae Helvetiae,57, 451-496.

AUBOUIN, J. 1965. Geosynclines. Amsterdam: Elsevier, 350 pp.

BONORINO, G. 1996, Foreland sedimentation and plate interaction during closure of the Tethys ocean (Tertiary; Hellenides; Western Continental Greece). Journal of Sedimentary Research, 66, 1148-1155.

BOUMA, A. H. 1962. The sedimentology of some Flysch deposits: a graphic approach to facies interpretation. Amsterdam: Elsevier, 168 pp.

FLEURY, J. 1980. Les zones de Gavrovo-Tripolitza et du Pinde-Olonus (Grece occidentale et Peloponnese du Nord): evolution d'une plateforme et d'une bassin dans leur cadre alpin. Société Géologique du Nord 4, 1-651.

JONES, G., DEWEVER, P. \& ROBERTSON, A.H.F. 1992. Significance of radiolarian age data to the Mesozoic tectonic and sedimentary evolution of the nothern Pindos Mountains, Greece. Geological Magazine, 129, 385400.

KATSIAVRIAS, N. 1983. The North Pindos Flysch : Flysch of the western part of the Gavrovo ridge . Northwestern Greece. Inst. Geol. Min. Expl., 126-139.

KOCH, K. E. \& NICOLAUS, H. J., 1969, Zur Geologie des ostpindos flysch beckens und seiner umrandung. Inst. for. Geol. Subsurf. Reser. Athens, raport no 9.

LORSONG, J. A., 1977, Stratigraphy of the Pindos flysch in the Politses mountains, Northwestern Greece. VI Coll. Aegean region, II, 703-714.

RICCI LUCCHI, F. 1975.Depositional cycles in two turbidite formations of Nothern Apennines (Italy). Journal of Sedimentary Petrology, 45, 3-432.

RICHTER, D., 1993, Die Flyschzonen Griechenlands VII. Sedimentstrukturen, Ablagerungsart und Schüttungsrichtungen im Flysch der Pindos-Zone (Griechenland): N. Jahrbuch für Geol. und Paläont., Monatshefte 9, 513-544.

RICHTER,D., MULLER, C., AND MIHM, A., 1993, Die Flyschzonen Griechenlands V. Zur Stratigraphie des Flysches der Pindos -Zone im nordlichen Pindos-Gebirge zwischen der albanischen Grenze und der Querzone von Kastaniotikos (Griechenland):N. Jahrbuch für Geol. Paläont., Monatshefte, 5, 257-291.

ROBERTSON, A. H. F., CLIFT, P. D., DEGNAN, P. J. \& JONES, G. 1991. Palaeogeographic and palaeotectonic evolution of the Eastern Mediterranean Neotethys. Palaeogeography, Palaeoclimatology, Palaeoecology, 87, 289-343.

STOW, D. A. V., READING, H. G. \& COLLINSON, J. D. 1996. Deep Seas. In Sedimentary Environments (ed. H. G. Reading), 395-453. 